\title{
Raw oysters can be a risk for infections
}

\section{Authors}

Regine Helena Silva dos

Fernandes Vieira

Oscarina Viana de Sousa

Renata Albuquerque Costa

Grace Nazareth Diogo

Theophilo 3

Andrew Macrae

Antonio Adauto Fonteles Filho $^{1}$

Dália dos Prazeres

Rodrigues $^{3}$

Institute of Marine Sciences, Fortaleza, CE, Brazil ${ }^{2} \mathrm{PhD}$ student in Fishery Engineering, UFC, Fortaleza, CE, Brazil

${ }^{3}$ Oswaldo Cruz Foundation, Rio de Janeiro, RJ, Brazil

${ }^{4}$ Institute of Microbiology

Prof. Paulo de Góes, Rio de Janeiro, RJ, Brazil

Submitted on: 08/13/2009 Approved on: 12/02/2009

Correspondence to:

Dra. Regine Helena Silva dos Fernandes Vieira Instituto de Ciências do Mar, Universidade Federal do Ceará

Av. da Abolição 3207,

Meireles, Fortaleza, CE, Brasil.

Tel: +55-85-3366-7027

Fax: +55-85 3366-7002

E-mail: reginevieira@terra. com.br

\begin{abstract}
The aims of this study were to count and identify sucrose positive and negative vibrios isolated from cultivated Crassostrea rhizophorae oysters during their growing cycle. Every month for 12 months, 10 to 18 oysters were collected for study. Collections occurred at the Center for Studies of Coastal Aquaculture (CSCA), which is associated with the Institute of Marine Science, Labomar, located in Euzebio, Ceará, Brazil. Approximately 150 oysters and their intervalvular liquor were studied. Vibrio Standard Plates Counts (SPC) from oyster meat and their intervalvular liquor varied from 25 to 59,000,000 CFU/g. For most of the 12 months of the oysters' life, it was possible to identify Vibrio parahaemolyticus. Vibrio carchariae was identified in four collections. Among other isolated species, the most important, considering public health risks, was $V$. vulnificus, although only one strain was confirmed. We concluded that retail purchased oysters should never be eaten raw or undercooked because many species of the genus Vibrio are known to be pathogenic to humans and live naturally on and in shellfish throughout their life cycle.
\end{abstract}

Keywords: Vibrio spp, oyster, public health, Vibrio parahaemolyticus, Vibrio carchariae.

[Braz J Infect Dis 2010;14(1):66-70] @Elsevier Editora Ltda.

\section{INTRODUCTION}

Over the last two decades, the intensification of penaeid shrimp culture industry and transportation of aquatic organisms worldwide have been accompanied by increased incidence of infectious pathogens ${ }^{1}$ and illnesses. In this context, Vibrio spp., a bacterium indigenous to coastal and marine environments, occasionally causes opportunistic human infections. ${ }^{2,3}$ Being an aquatic bacteria, species of the genus Vibrio infect not only humans but also all aquatic animals, resulting in problems in shrimp and shellfish farming. Aquatic animals once infected with any Vibrio species should not be consumed raw to avoid the risk of illness. Vibrios are prevalent in warm estuarine areas throughout the world. In the United States virtually all human infections caused by $V$. vulnificus result from the consumption of oysters harvested from the Gulf of Mexico. ${ }^{4,5}$ Vibrio parahaemolyticus and Vibrio cholerae are species that can also cause gastroenteritis and may result in more severe infections than those caused by sewage-borne viral and bacterial pathogens. ${ }^{5}$ The aims of this study were to count and identify sucrose positive and negative vibrios, isolated from cultivated oysters, from juvenile to commercial marketing size.

\section{MATERIAL AND METHODS}

\section{Field sampling sites}

Crassostrea rhizophorae oysters were collected from the Center for Studies of Coastal Aquaculture (CSCA) which is associated with the Institute of Marine Science, Labomar, located in Euzebio, Ceará, Brazil (Figure 1). Oysters were selected for study based on their size and growth cycle stage.

Figure 1: Map of the sampling site for mangrove oyster, Crassostrea rhizophorae, located at Center for Studies of Coastal Aquaculture (CSCA) in Euzébio, Ceará state, Brazil.

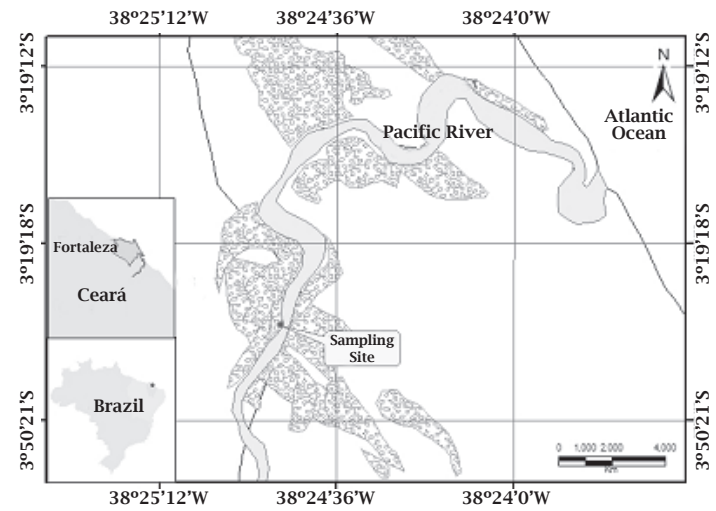




\section{Sample collection}

Every month for 12 months, 10 to 18 oysters were collected for study. After 12 months, the oysters reached commercial size and were sold at market places. Approximately 150 oysters and their intervalvular liquor were studied. The $\mathrm{pH}$ of oyster meat and intervalvular liquor was measured immediately after opening.

\section{Bacteriological count and isolation}

Monthly, oysters were collected from their oyster bed at CSCA in Euzebio. They were put in a box with ice and transported under aseptic conditions to the Environmental Microbiology Laboratory at Labomar where the samples were processed. One gram of oyster meat was mixed with $10 \mathrm{~mL}$ of a sterile saline solution (1\%). From these, serial dilutions were prepared $\left(10^{-2}\right.$ to $\left.10^{-4}\right)$ using sterile saline solution (1\%) in test tubes. From each dilution $0.2 \mathrm{~mL}$ was spread onto Thiosulfate Citrate Bile Salts Sucrose (TCBS) agar media in duplicate and the plates were incubated at $36^{\circ} \mathrm{C}$ for 18 to 24 hours. The colonies that grew on the plates were counted and the sucrose positive and negative colonies were recorded. Sucrose positive and negative Vibrio isolates were streaked for purity onto Tryptone Soy Agar (TSA) supplemented with $1 \% \mathrm{NaCl}$. The pure strains were sent to the Oswaldo Cruz Foundation in Rio de Janeiro where they were identified.

\section{Vibrio identification}

From growth on TCBS agar, 3 to 4 colonies were transferred to Trypticase Soy Agar (TSA) slants and incubated at $35^{\circ} \mathrm{C} / 24 \mathrm{~h}$. Isolates were identified using the phenotypic tests described by Alsina and Blanch ${ }^{6}$ and Elliot et al. ${ }^{7}$ Tests included bacterioscopy by Gram staining; motility (SIM), production of cytochrome oxidase test; TSI reaction; arginine hydrolysis, and lysine and ornithine decarboxylation; halophilic differ- entiation test (at $0,3,6,8$ and $10 \% \mathrm{NaCl}$ ); acetoin production (Voges-Proskauer test); growth at $42^{\circ} \mathrm{C}$; hydrolysis of onitrophenyl- $\beta$-D-galactopyranoside (ONPG); carbohydrate fermentation (glucose, mannitol, lactose, sucrose, arabinose, and mannose), and the indole production test.

\section{RESULTS AND DISCUSSION}

The Vibrio Standard Plate Counts (SPC) from the oysters and their intervalvular liquor varied from 25 to $59,000,000$ CFU/g (Table 1). Vibrio counts varied enormously and followed no logic. Even smaller individuals (less than $2.5 \mathrm{~cm}$ in diameter, collection 1) showed higher Vibrio counts than those with $4,67 \mathrm{~cm}$ in diameter of collection 5 (Figure 2). Sometimes, even on the lowest dilutions it was not possible to find counting between 25 and 250 colonies, and that's why, in results, the estimated colony forming unit per gram (CFU/g est) was used (collections 2, 5 and 6 - Table 1).

After 12 months, oysters reach a $6.41 \mathrm{~cm}$ diameter or larger and may be commercialized. From previous studies and according to literature, it is known that there are two main environmental conditions influencing numbers of cultivable Vibrio spp. from coastal environments. First, temperature has a marked influence on the occurrence of vibrios and secondly, seawater salinity exerts a strong influence on the survival of Vibrio spp. ${ }^{8,9}$ Northeastern Brazilian coastal waters temperatures are warm and this might explain the high Vibrio counts recorded in this study (Table 1). Barros et al. ${ }^{10}$ found lower values for Vibrio counts from raw oyster meat. Their counts ranged from 93 to 9,300 Vibrio spp./g and these differences may be a result of using the Maximum Probable Number count method and not SPC. In their study, oyster meat was stored frozen before being investigated and we have already shown that freezing negatively influences growth of Vibrio species. ${ }^{11}$ Brazilian regulations neither define safe Vibrio numbers limits for fish

Figure 2: Monthly variation of the estimates of log Vibrio CFU/g and individual size for farmed mangrove oyster, Crassostrea rizophorae, collected in Euzébio, Ceará state, Brazil.

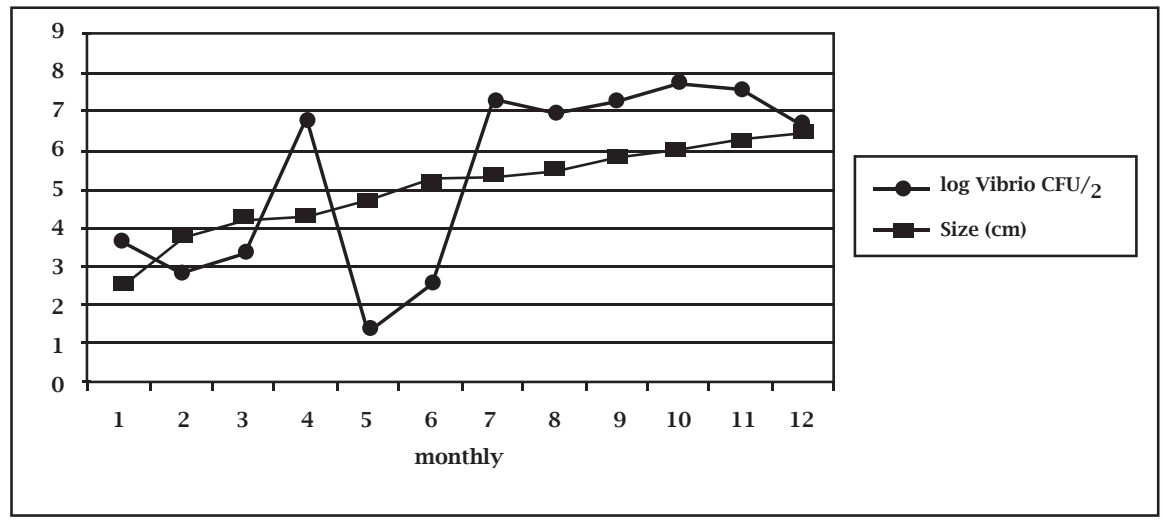


Table 1. Vibrio sucrose positive and negative standard plate count (spc), individual size and pH on Mangrove Oyster, Crassostrea rizophorae, collected in Euzébio, Ceará state, Brazil

\begin{tabular}{|c|c|c|c|c|c|c|c|c|}
\hline Month & $\begin{array}{c}\text { Total count of } \\
\text { Vibrio CFU/g }\end{array}$ & Log & $\begin{array}{c}\text { Sucrose } \\
+ \text { +ive }\end{array}$ & Log & $\begin{array}{c}\text { Sucrose } \\
\text {-ive }\end{array}$ & Log & Size (cm) & pH \\
\hline 1 & 5,200 & 3.71 & 3,500 & 3.54 & 1,700 & 3.23 & 2.50 \\
\hline 2 & 750 est. & 2.87 & 750 & 2.87 & $<10$ & - & 3.77 \\
\hline 3 & 2,500 & 3.39 & 2,500 & 3.39 & $<10$ & 4.25 \\
\hline 4 & $7,025,000$ & 6.84 & $2,775,000$ & 6.44 & $4,250,000$ & 6.62 & 4.34 & 6.47 \\
\hline 5 & 25 est. & 1.39 & 25 est. & 1.39 & $<10$ & - & 4.67 \\
\hline 6 & 375 est. & 2.57 & 100 est. & 2.0 & 275 est. & 2.43 & 5.23 \\
\hline 7 & $23,850,000$ & 7.37 & $19,775,000$ & 7.29 & $4,075,000$ & 6.61 & 5.35 \\
\hline 8 & $9,575,000$ & 6.98 & $5,450,000$ & 6.73 & $4,125,000$ & 6.61 & 5.48 \\
\hline 9 & $20,750,000$ & 7.31 & $9,750,000$ & 6.98 & $11,000,000$ & 7.04 & 5.85 \\
\hline 10 & $59,000,000$ & 7.77 & $41,500,000$ & 7.61 & $17,500,000$ & 7.24 & 6.05 \\
\hline 11 & $37,500,000$ & 7.57 & $7,250,000$ & 6.86 & $30,250,000$ & 7.48 & 6.69 \\
\hline 12 & $4,975,000$ & 6.69 & $1,500,000$ & 6.17 & $3,475,000$ & 6.54 & 6.41 \\
\hline
\end{tabular}

products nor restrict consumption based on numbers. ${ }^{12}$ One of the consequences of this lack of regulations is that it has been difficult to monitor and develop indicators for Vibrio spp. due to their ubiquitous occurrence in coastal waters and the lack of physiological characteristics shared with human enteric bacteria. ${ }^{13-15}$

The $\mathrm{pH}$ of oysters' meat plus the intervalvular liquor varied from 6.41 to 7.78 (Table 1). Usually, these are not the best values for Vibrio growth. These bacteria grow better under alkaline conditions and Donovan \& Netten ${ }^{16}$ suggest that the optimum $\mathrm{pH}$ range for selective growth of vibrios is 8.4-8.6. The outcome of this experiment confirms this fact since the lowest counts of vibrios ( $25 \mathrm{CFU} / \mathrm{g}$ est.) were found in the samples with the lowest $\mathrm{pH}$ (Table 1, Figure 3).
During most of the oyster's 12 month lifespan it was possible to identify Vibrio parahaemolyticus (Table 2). The prevalence of this species in seafood corroborates reports from other countries. ${ }^{17-19}$ Similar results were obtained by Lowry et al..$^{20}$ who found $100 \%$ of the raw oysters examined to contain V. parahaemolyticus. Studies have also shown that a population of $V$. parahaemolyticus in unrefrigerated oysters can increase rapidly from 50 to 790 times their original numbers within 24 hours of harvest if left at $26^{\circ}$ C. ${ }^{21} \mathrm{~A}$ survey of 370 lots of oysters sampled from restaurants, oyster bars, retail, and wholesale seafood markets throughout the US between June 1998 and July 1999 found a seasonal distribution of V.parahaemolyticus in market oysters with the highest densities detected during summer months. ${ }^{22}$ The greatest challenge for

Figure 3: Monthly variation of the estimates of log Vibrio CFU/g and pH for farmed mangrove oyster, Crassostrea rizophorae, in Ceará state, Brazil.

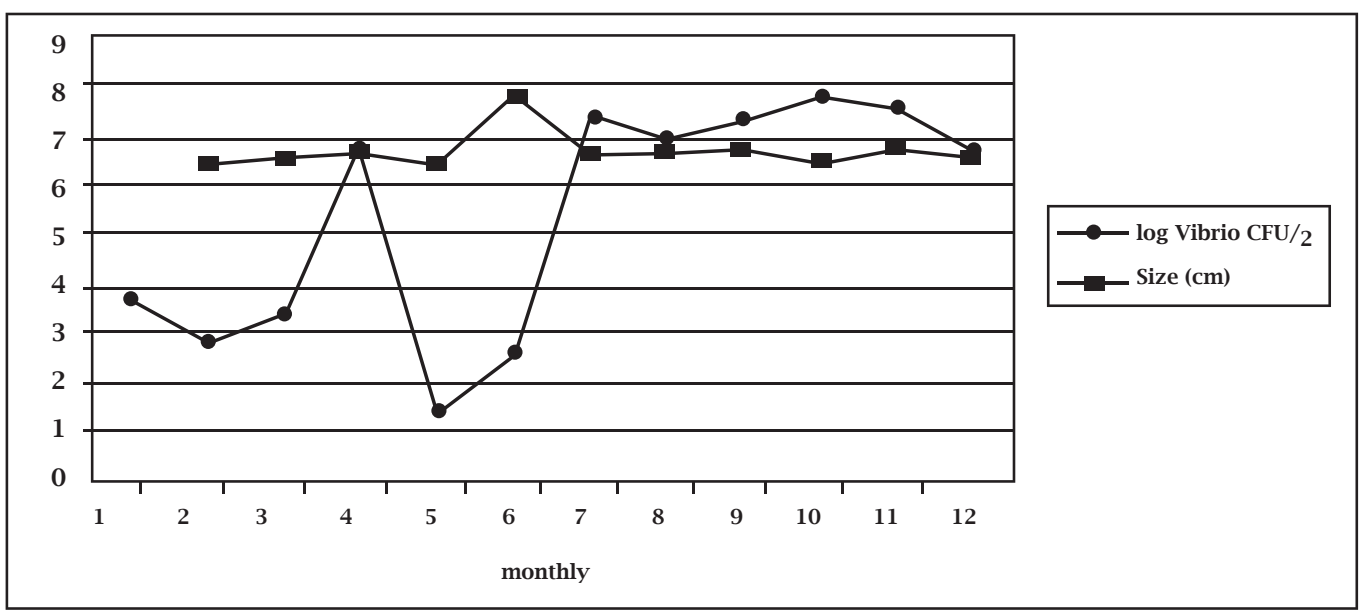


Table 2. Vibrio Strains Identified on Mangrove Oyster, Crassostrea rhizophorae, in Euzébio, Ceará State, Brazil

\begin{tabular}{llll}
\hline Month & *n & $\mathbf{N}^{\mathbf{0}}$ of strains & Vibrio species \\
\hline 1 & 14 & 3 & V. fluvialis (1), V. parahaemolyticus (1), V. vulnificus (1) \\
\hline 2 & 10 & 3 & Vibrio sp. (1), V. pelagius Biogroup 2 (2) \\
\hline 3 & 15 & 1 & Vibrio sp. \\
\hline 4 & 14 & 2 & V. parahaemolyticus (2) \\
\hline 5 & 12 & 1 & V. carchariae (1) \\
\hline 6 & 13 & 5 & V. parahaemolyticus (1), V. alginolyticus (4) \\
\hline 7 & 18 & 3 & V. damsela (1), V. parahaemolyticus (2) \\
\hline 8 & 12 & - & - \\
\hline 9 & 11 & 3 & $\begin{array}{l}\text { V. parahaemolyticus (1), V. carchariae (1), V. cholerae non O1, } \\
\text { non O139 (1) }\end{array}$ \\
\hline 10 & 12 & 2 & V. parahaemolyticus (1), Vibrio sp. (1) \\
\hline 12 & 14 & 10 & $\begin{array}{l}\text { V. furnissii (1), V. parahaemolyticus (1), V. alginolyticus (2), } \\
\text { V. carchariae (2), V. harveyi (2), Vibrio sp. (2). }\end{array}$ \\
\hline
\end{tabular}

* $\mathrm{n}=$ number of oyster.

the safe consumption of oysters is to get them refrigerated or frozen immediately after harvest and to market them as soon as possible. Consumption of raw or undercooked seafood, particularly shellfish, contaminated with V.parahaemolyticus may lead to the development of acute gastroenteritis characterized by diarrhea, headache, vomiting, nausea, abdominal cramps, and slight fever. This bacterium is recognized as the leading cause of human gastroenteritis associated with seafood consumption in the United States and an important seafood-borne pathogen throughout the world. ${ }^{23}$ Although the gastroenteritis caused by $V$. parahaemolyticus infection is often self-limited, the infection may cause septicemia that is life-threatening to people having underlying medical conditions, such as liver disease or immune disorders. Two deaths were reported among three cases of wound infections caused by $V$. parahaemolyticus in Louisiana and Mississippi after Hurricane Katrina in 2005. ${ }^{24}$ Vibrio carchariae was identified in four of the monthly oyster collections and it has also been found on a chronic skin ulcer on a shark, Carcharhinus plumbeus (Nardo), kept in the Genoa Aquarium, Italy. Identification through fatty acid composition analysis and biochemical tests showed that $V$. carchariae were the predominant bacteria isolated from the ulcer. ${ }^{25}$ Pedersen et al. ${ }^{26}$ described $V$. carchariae as a synonym of $V$. harveyi based on ribotyping. Vibrio carchariae, a species isolated from sharks, belongs to its normal skin flora, but may become pathological when the animal is under stress. Vibrio carchariae has been described as an etiologic agent for some fish in cultivations. ${ }^{27}$ Pereira et al. ${ }^{28}$ reported that forty samples of mangrove oysters (Crassostrea rhizophorae) served raw in 15 restaurants in Rio de Janeiro were evaluated in order to investigate the presence of Vibrio spp. They found that Vibrio parahaemolyticus,
Vibrio carchariae, Vibrio alginolyticus and Vibrio vulnifcus were the main species (> $60 \%$ ) isolated from raw oysters. Other species were identified as well, and despite being found in smaller numbers they were of no less importance (Table 2). Among those of most importance regarding public health was $V$. vulnificus, but only one strain was confirmed. Because oysters, in most places, are consumed without being cooked they can easily turn into a potentially health-hazard in food consumption.

In this study we counted and identified large numbers of potentially pathogenic Vibrio spp. from juvenile to commercial sized oysters. They are ubiquitous and can multiply to dangerous numbers very quickly. We concluded that market purchased shellfish should never be eaten raw or undercooked because many species of the genus Vibrio, which naturally live on and in shellfish throughout their life cycle, are known to be pathogenic to humans.

\section{ACKNOWLEDGEMENTS}

The authors acknowledge the financial support of CNPq.

\section{REFERENCES}

1. Saulnier D, Haffner P, Goarant C, Levy P, Ansquer D. Experimental infection models for shrimp vibriosis studies: a review. Aquaculture 2000; 191:133-44.

2. Hlady WC, Klontz KC. The epidemiology of Vibrio infections in Florida, 1981-1993. J Infect Dis 1996; 173:1176-83.

3. Fyfe M, Kelly MT, Yeung ST et al. Outbreak of Vibrio parahaemolyticus infections associated with eating raw oysters Pacific Northwest, 1997. MMWR 1998; 47:457-62. 
4. Watkins WD. Overview of the Vibrio vulnificus problem. pp. 9-12. In: Proceedings of the 1994 Vibrio vulnificus Workshop. Food and Drug Administration, NOAA and ISSC, Washington, DC.

5. Rippey SR. Infectious diseases associated with molluscan shellfish consumption. Clin. Microbio. Rev. 1994; 7:419-25.

6. Alsina M, Blanch AR. Improvement and update of a set of keys for biochemical identification of environmental Vibrio species. J. Appl. Bacteriol. 1994; 77:719-21.

7. Elliot EL, Kaysner CA, Jackson L, Tamplin ML. Vibrio cholerae, V. parahaemolyticus, V. vulnificus and other Vibrio spp. In: Food and Drug Administration - FDA, Bacteriological Analytical Manual. FDA, Center for Food Safety and Applied Nutrition - CFSAN, 2001.

8. Elliot EL, Kaysner CA, Jackson L, Tamplin ML. Vibrio cholerae, V. parahaemolyticus, V. vulnificus and other Vibrio spp. Bacteriological Analytical Manual, Food and Drug Administration. 8th Edition, Chap. 9, pp. 9.01-9.27. AOAC International, Gaithersburg, MD, USA, 1995.

9. Motes ML, DePaola A, Cook DW et al. Influence of water temperature and salinity on Vibrio vulnificus in Northern Gulf and Atlantic Coast oyster (Crassostrea virginica). Appl Environ Microbiol 1998; 64:1459-65.

10. Barros LMO, Sousa OV, Lima EA et al. Víbrios sacarose negativos isolados de ostras Crassostrea rhizophorae comercializadas em barracas de praia na cidade de Fortaleza, Ceará, Brasil. Bol. Tec. Cient. Cepnor 2007; 7(1): 9-16.

11. Sousa DBR. Recuperação de cepas de Vibrio parahaemolyticis inoculadas em camarão marinho Litopenaeus vannamei submetidas às temperaturas de resfriamento e congelamento. 2007. 50f. Dissertação (Mestrado em Engenharia de Pesca) Departamento de Engenharia de Pesca. Universidade Federal do Ceará, 2007.

12. Brasil. Agência Nacional de Vigilância Sanitária. RDC no 12 de 02 de janeiro de 2001. Ministério da Saúde, 2001.

13. Rodrick GE, Blake NJ, Tamplin ML et al. The relatonship between fecal coliforms levels and occurrence of vibrios in Apalachicola Bay, Florida. In: Colwell R.R. eds. Vibrios in the Environment. John Wiley and Sons, NY, NY, USA: 1984; pp.567-75.

14. Tamplin ML, Rodrick GE, Blake NJ et al. Public health aspects of halophilic vibrios in Jamaica. West Indian Med J 1983; 32:147-51.

15. Tamplin M, Rodrick GE, Blake NJ et al. Isolation and characterization of Vibrio vulnificus from two Florida estuaries. Appl Environ Microbiol 1982; 44:1466-70.
16. Donovan TJ, Netten P. Culture media for the isolation and enumeration of pathogenic Vibrio species in foods and environmental samples. Int J Food Microbiol. 1995; 26:77-91.

17. Chan KY, Woo ML, Lam LY, French GL. Vibrio parahaemolyticus and other halophilic vibrios associated with seafood in Hong Kong. J. Appl. Bacteriol. 1989; 66:57-64.

18. Parveen S, Hettiarachchi KA, Bowers JC et al. Seasonal distribution of total and pathogenic Vibrio parahaemolyticus in Chesapeake Bay oysters and waters. Int J Food Microbiol. 2008; 128:354-61.

19. Su YC, Liu C. Vibrio parahaemolyticus: A concern of seafood safety. Food Microbiology 2007; 24: 549-58.

20. Lowry PW, McFarland LM, Peltier NC et al. Vibrio gastroenteritis in Louisiana: a prospective study among attendees of a scientific congress in New Orleans. J. Infect. Dis. 1989; 160:978-84

21. Gooch JA, DePaola A, Bowers J, Marshall DL. Growth and survival of Vibrio parahaemolyticus in postharvest American oysters. J. Food Prot. 2002; 65:970-74.

22. Cook DW, O'leary P, Hunsucker JC et al. Vibrio vulnificus and Vibrio parahaemolyticus in U. S. retail shell oysters: a national survey June 1998 to July 1999. J. Food Prot. 2002; 65:79-87.

23. Kaysner CA, DePaola A. Vibrio. pp. 405-20. In: Downes F.P., Ito K. eds. Compendium of Methods for the Microbiological Examination of Foods, 4th Edition. American Public Health Association, Washington, DC, 2001.

24. Center for Disease Control and Prevention (CDC). Vibrio illnesses after Hurricane Katrina - Multiple States, August-September 2005. Morb. Mortal. Wkly. Rep. 2005; 54:928-31.

25. Bertone S, Gili C, Moizo A, Calegari L. Vibrio carchariae associated with a chronic skin ulcer on a shark, Carcharhinus plumbeus (Nardo). J Fish Dis. 1996; 19:429-34.

26. Pedersen K, Verdonck L, Austin B et al. Taxonomic evidence that Vibrio carchariae Grimes et al. 1985 is a junior synonym of Vibrio harveyi (Johnson and shunk 1936) Baumann et al. 1981. Int J Syst Bacteriol 1998; 48:749-58.

27. Lee KK, Liu PC, Chuang WH. Pathogenesis of gastroenteritis caused by Vibrio carchariae in cultured marine fish. Marine Biotechnology 2002; 4:267-77.

28. Pereira CS, Viana CM, Rodrigues PD. Vibrios patogênicos em ostras (Crassostrea rhizophorae) servidas em restaurantes no Rio de Janeiro: um alerta para a Saúde Pública. Rev. Soc. Bras. Med. Trop. 2007; 40(3):300-03. 